\title{
Sovereign Wealth Funds: Russian and International Experience
}

Mikhail Evgenievich Kosov, ${ }^{\dagger *}$ Aleksandr Victorovich Sigarev, ${ }^{\dagger ¥}$ Vitaly Filippovich Sharov, $^{\dagger}$ Olga Vladilenovna Makashina ${ }^{\dagger}$ and Vladimir Mikhailovich Smirnov ${ }^{\dagger}$

\section{Abstract}

Taking the Russian and the International experience, the principal aim of this study is to analyse sovereign wealth funds critically.

It remains well known that the Russian National Wealth Fund is vital in the macroeconomic policy of the Russian state. After the abolition of the Reserve Fund in 2018, the Russian National Wealth Fund has to solve a wide range of tasks. In this context, one can argue that the sovereign welfare fund is a specialised monetary fund used to stabilise the state budget when government revenues decline. The welfare fund is also used to finance government needs in the long-term period. The role of sovereign wealth funds is growing in the world. They accumulate large amounts of financial resources. Sovereign wealth funds are founded in such countries where the budget strongly depends on market factors. In most cases, these factors are global commodity prices. The funds' money is used to cover the deficit of the relevant budget in case of unfavourable market shifts. In the period of high commodity prices, the fund accumulates an excess of export earnings. Against this backdrop, the key purpose of the study is to evaluate the efficiency of managing the National Wealth Fund in the Russian Federation. The study was carried out using the methods of synthesis, analysis, economic analysis, as well as graphic methods, and the methods of comparisons and analogies, which in turn helps in evaluating the extent of efficiency of managing the Russian National Wealth Fund.. The research findings can be used when developing an investment strategy (investment portfolio) of the Russian National Wealth Fund, through which it can aim at balancing the insurance pension system, financing of the federal budget deficit, and co-financing of voluntary pension savings. In this regard, it is imperative for the fund to perform in productive investment activities.

Keywords: Global Financial Market; Sovereign Wealth Funds; Investments; Investment Portfolio

\footnotetext{
${ }^{\dagger}$ Financial University under the Government of the Russian Federation, 49 Leningradsky Avenue, Moscow, 125993, Russia

${ }^{*}$ Corresponding Author, Email: m.e.kosov3191@gmail.com

¥ Plekhanov Russian University of Economics, 36 Stremyanny Lane, Moscow, 117997, Russia

(C) 2020 Kosov et al. This is an Open Access article distributed under the terms of the Creative Commons Attribution License (http://creativecommons.org/licenses/by/2.0), which permits unrestricted use, distribution, and reproduction in any medium, provided the original work is properly cited.
} 


\section{Introduction}

Today the most critical problem is to pursue an effective policy in the area of public financial reserves, in particular, their use for the development of the national economy and the modernisation of industry, as well as ensuring the balance of the leading macroeconomic indicators.

The formation and use of state financial reserves are determined mainly by ensuring the balance of the leading macroeconomic indicators of the state.

One of the leading modes of forming and applying state money reserves is the creation of a special fund of state money reserves and the legislative determination of its formation, placement and expenditure. The declared purposes of the creation of the fund of money reserves are to provide the dynamic balance of the federal budget and to stabilise the state economy, to supply future generations with sources of profits while depleting natural resources. The developed Money Reserves Fund is considered to be the subject of financial and budget planning and forecasting, and its functioning is associated with the state of the federal budget.

The study of state financial reserves should involve the study of several issues. First, those associated with the formation of such reserves, and, further, their application. In addition, the issues of their application are classified into two sub-issues: the difficulties that may arise when placing and spending state financial reserves. The approach to solving these difficulties and problems should be based on deepening both theoretical and methodological ideas about the creation and spending of state financial reserves to provide measures to control and protect the development of the state economy.

For ensuring the economic security, among other things, states found sovereign wealth funds (SWFs).

To ensure the economic security of the state, the central role of the SWFs is as follows: 1 ) the fund's money is used to cover the state budget deficit in case of an unfavourable situation, 2) the fund's money can restrain strengthening of the real exchange rate of the national currency, and 3 ) in the period of high prices for raw materials, the fund allows accumulating excess export earnings and prevent the development of the "Dutch disease of the economy" (increase in inflation, rejection of the development of the industrial sector of the economy and other negative factors). SWFs have an impact on public investment management, a change in monetary policy in the country.

The role of SWFs in public financial management can appear in regulating inflation, exchange rates, government loans, and economic growth. By participating in the regulation of financial and economic processes in the country, the SWF affects the reduction of corruption. An intensive increase in the money supply in the private sector of the economy affects the efficiency of functioning as a guarantor of national security. Thus, the activity of the state becomes focused on upholding the interests of oligarchs and commercial structures close to them. Let us consider in more detail the mechanisms of development of SWF in order to increase the efficiency of functioning:

1) The SWF mechanism can reduce inflation in the country. The inflation can increase in case of a large inflow of funds into the economy from abroad when receiving payments for the export of goods or services. If a large part of this money is not spent on goods and services of local production, it stimulates domestic demand (demand exceeds supply) and may cause overheating of the economy if there are not enough opportunities to satisfy the additional domestic demand. Besides, the inflow of foreign funds into the economy increases inflation due to the growth of deposits in the local banking system, which, in turn, stimulates the credit supply.

One of the mechanisms SWFs use to influence inflation is to use them to reduce currency inflows. Instead of converting the funds received from abroad into local currency and spending 
them, a part of these funds can be stored in a foreign currency and invested abroad using SWFs.

2) The SWF mechanism can reduce expenses on government loans. The investors who invest their funds in the public debt take into account a number of factors when choosing an investment object. In addition to other things, they pay attention to the profitability of bonds, the probability of the principal amount to be repaid in full; as well as the currency, the debt is denominated in.

Investors tend to provide loans under more favourable terms and conditions to the countries that have SWFs because assets will often be stored in "safe" currencies, such as the US dollar or euro. Besides, the availability of SWFs can mean for investors a reduction in the default risk because the SWFs can be used in case of a crisis.

3) The SWF mechanism may limit the growth of the exchange rate of the national currency. A sharp inflow of foreign currency into the economy can cause a "Dutch disease of the economy", when an increase in the rate of the national currency may impair the competitiveness of sectors of the national economy that are dependent on exports, for example, the industrial sector.

The study analyses the features of the functioning of SWFs at the international level. The features of the National Welfare Fund and its role in the implementation of strategic macroeconomic objectives are also considered.

We used data of the past ten years from the Institute of National Welfare Fund SWFI and the Ministry of Finance of the Russian Federation. The data was taken from sources published in scientific journals, websites of the Institute of National Welfare Fund SWFI and the Ministry of Finance of the Russian Federation, as well as open access resources. These data are not a commercial or state secret.

The study provides detailed research results that can be used to develop an investment strategy. It begins with a description of the materials and methods employed for this study. Following this, it critically discusses the results.

\section{Materials and Methods}

Macroeconomic and foreign policy crises show that the strategic importance of sovereign funds founded by the countries that earn market superprofits is increasing.

There is a large literature devoted to sovereign funds, some of which are - J. Aizenman and R. Glick (2009), R. Beck and M. Fidora, (2008), S. Bernstein et al. (2013), B. Bortolotti et al. (2015), G.L. Clark et al. (2013), B.J. Cohen (2009), K.L. Dewenter et al. (2010), R.J. Gilson and C.J. Milhaupt (2008), D. Haberly (2011), E. Helleiner (2009), S.A. Johan et al. (2013), S. Johnson (2007), R.M. Kimmitt, (2008), A. Knill et al. (2012a, 2012b), J. Kotter and U. Lel (2011), A. Monk (2009), A.K. Rose and M.M. Spiegel (2004), and V. Shih (2009).

From these literature, it is easy to assume that in common practice it is more rational to separate export superprofits. Otherwise, they affect the economy (Sigarev et al., 2018). An example is the Groningen effect, which means a disproportionate increase in social expenses; an excessive number of public officials; an increase in expenditures for defence; taking measures to improve the image of the state in the prejudice of cost optimisation; the extensive nature of economic development; and the suspension of production modernisation.

Due to the destabilising impact of market revenues, objective macroeconomic conditions, there is a need to apply special principles of the state budget formation in the countries that earn high incomes by using natural resources.

The commodity income management in the states that are dependent on world energy prices can be based on the following rules:

1) It is necessary to save only a part of raw materials' income; the other part can be used to cover the budget deficit in the form of "constant consumption" and "average price",

2) To fully save the income earned. The so-called "total savings' rule" implies that all earned raw materials' income is being stored in a sovereign fund. It is worth noting the importance of covering non-energy shortages. It is necessary to 
observe the rule that the formed non-energy shortage is covered only by using the real income earned as a result of placing sovereign fund money. To control the raw material budget dependence, the non-energy deficit is calculated as a percentage of GDP. The "total savings' rule" requires the bringing of the sovereign fund to the country's GDP.

The world practice of managing raw material income in the countries that are dependent on hydrocarbons' export shows the efficiency of using the following approaches: "total savings" policy, partial saving of the earned raw materials' income and using the remaining part to finance the budget deficit (the "constant consumption" rule), and the "average price" rule. In this case, "total savings" mean the accumulation of raw materials' income in sovereign funds.

At the same time "constant consumption" limits the expenditure item of the country's budget at the expense of the limit of the earned raw materials income and allows pursuing the counter-cyclical budget policy. Consequently, in the case of the GDP decrease, the budget expenditures carried out by using raw materials income are reduced. The optimal amount of the transfer to the budget due to the income earned from the export of raw materials is the profitability of the present value of the raw material infrastructure of the country (Dubovik et al., 2018). The "constant consumption" approach requires such a fiscal policy that will aim at limiting the growth rate of the budget expenditures, will ensure a balance of growth rates of nominal GDP, and a gradual reduction of the non-resource budget deficit.

Since 2005, 40 sovereign funds have been founded in the world. As a rule, they do not participate in the formation of the country's macroeconomic policy, except for the following cases: transfer of funds to the budget (in exceptional cases) for the needs of the central bank or when restoring the payment balance. From 2003 through 2013, there was a positive trend of increasing the volume of funds in various states. At the same time, rapid rates prevailed in the countries earning the income from exporting oil products.

At the same time, the distribution of the SWFs formed from oil and gas revenues revealed a clear dependence of countries by their geographical location of hydrocarbon production. In its turn, this allows formulating a hypothesis about the creation of prerequisites for ensuring a technological breakthrough in innovative sectors of the economy within the long-term state sovereignty.

Along with this, the total amount of the formed SWFs in the world economy is USD 7.421 billion, with the countries that use other types of funds rather than raw materials' ones accounting for $39.57 \%$ of the amount (Table 1 ).

A high share of SWFs formed in Asia and Oceania (98.31\%) as compared to other global segments provides considerable volumes, primarily due to People's Republic of China (the SAFE Investment Company funds, National Social Security Fund, China Investment Corporation, Africa Development Fund) in the amount of USD 1,520.6 billion, the Republic of Singapore (funds of GIC Private Limited, Temasek Holdings) - USD 537.6 billion, South Korea (fund of the Korea Investment Corporation) - USD 91.8 billion, and Australia (Australian Future Fund) USD 89.8 billion, respectively. 


\begin{tabular}{|c|c|c|c|c|}
\hline Rank & Fund & Country & Fund type & $\begin{array}{l}\text { Volume, } \\
\text { USD bln. }\end{array}$ \\
\hline 1 & Social Security Trust Funds & USA & Pension State Fund & $2,801.50$ \\
\hline 2 & $\begin{array}{l}\text { Government Pension Investment } \\
\text { Fund }\end{array}$ & Japan & Pension State Fund & $1,492.40$ \\
\hline 3 & Government Pension Fund - Global & Norway & National Wealth Fund & 996.00 \\
\hline 4 & $\begin{array}{l}\text { Abu Dhabi Investment Authority } \\
\text { (ADIA) }\end{array}$ & UAE & National Wealth Fund & 773.00 \\
\hline 5 & China Investment Corporation (CIC) & $\begin{array}{l}\text { People's } \\
\text { Republic of } \\
\text { China }\end{array}$ & National Wealth Fund & 746.70 \\
\hline 6 & SAMA Foreign Holdings & Saudi Arabia & National Wealth Fund & 685.60 \\
\hline 7 & Kuwait Investment Authority (KIA) & Kuwait & National Wealth Fund & 592.00 \\
\hline 8 & SAFE Investment Company & $\begin{array}{l}\text { People's } \\
\text { Republic of } \\
\text { China }\end{array}$ & National Wealth Fund & 541.90 \\
\hline 9 & $\begin{array}{l}\text { National Pension Service of Republic } \\
\text { of Korea }\end{array}$ & South Korea & Pension State Fund & 455.00 \\
\hline 10 & Stichting Pensioenfonds ABP & Netherland & Public Pension Fund & 440.00 \\
\hline 11 & $\begin{array}{l}\text { Hong Kong Monetary Authority } \\
\text { Investment Portfolio }\end{array}$ & Honk Kong & National Wealth Fund & 427.70 \\
\hline 12 & Federal Retirement Thrift & USA & Public Pension Fund & 422.20 \\
\hline 13 & GIC Private Limited & Singapore & National Wealth Fund & 344.00 \\
\hline 14 & CalPERS & USA & Public Pension Fund & 304.10 \\
\hline 15 & Qatar Investment Authority & Qatar & National Wealth Fund & 256.00 \\
\hline
\end{tabular}

The SWF of the China Investment Corporation (CIC) is the largest by volume in the group of countries under study. It was formed on 29 September 2007 with an amount of USD 746.7 billion and is wholly owned by the state. The fund is registered with a registered capital of USD 200.0 billion. At the same time, the main goal of the fund is to diversify the currency reserves of the PRC in order to earn the maximum income when placing a portfolio of investments on the stock market in the form of government securities and bonds, hedge funds, real estate investments, direct investments in private companies, as well as monetary funds, deposits and US Treasury bills.

Thus, in its policy, the $\mathrm{CIC}$ fund provides for strategic allocation of assets, corresponding to the formation of an investments portfolio, taking into account their tactical allocation by classes and investment ranges, pursuing long-term goals and evaluating possible risk factors. The share of internal asset management in the PRC as compared to the international ones is $67 \%$ to 32 $\%$, respectively. As on 01 January 2015 the total investment portfolio of the $\mathrm{CIC}$ fund is allocated as investments in:

- Shares for the short-term period - 44.1 $\%$,

- Long-term securities - $26.2 \%$,

- Earning a fixed income on securities $14.6 \%$,

- Bringing absolute profitability - $11.5 \%$, and

- Monetary funds and other instruments $3.6 \%$.

The correction of the investments portfolio of the $\mathrm{CIC}$ fund by their efficiency, taking into account the existing macroeconomic policy in 2015 , concerning investments in securities that 
bring the fixed income was correlated in the following proportion: $57.4 \%$ was for sovereign bonds of the countries with developed economies, $24.9 \%$ - bonds of corporations operating in the investment sector of the economy, and $17.7 \%$ - sovereign bonds of the countries with developing economies, respectively.

To further adapt to the current macroeconomic circumstances, in 2015 the $\mathrm{CIC}$ fund introduced continuous monitoring of the investment portfolio in the form of creating a multilevel analytical system of risk warnings and assessment by tightening the internal control, above all, over operating expenses.

All those measures made it possible to improve the efficiency of the current policy and create prerequisites for the further development of the strategic horizon of the fund's assets.

\section{Results}

The primary purpose of the Russian National
Wealth Fund is to form additional financial resources to cofinance voluntary pension savings (the cumulative part of the pensions was frozen since 2014) of the Russian citizens and to ensure balance (to cover deficit) of the budget of the Pension Fund of the Russian Federation. The reserve fund was intended to cover the budget deficit. At the same time, it is necessary to note that Russian funds operate on the accounts of the Central Bank, invest funds on its behalf; and the money of these funds is recognised as a part of the gold and foreign currency reserves to match the reliability rating according to the IMF AA-classification of Fitch-Ratings or Standard \& Poor's rating agencies, not lower than Aa3, ${ }^{1}$ according to the classification of the Moody's Investors Service rating agency. Today, about $78 \%$ of the NWF portfolio is represented mainly in foreign currencies/assets (dollars, euros, and pounds).

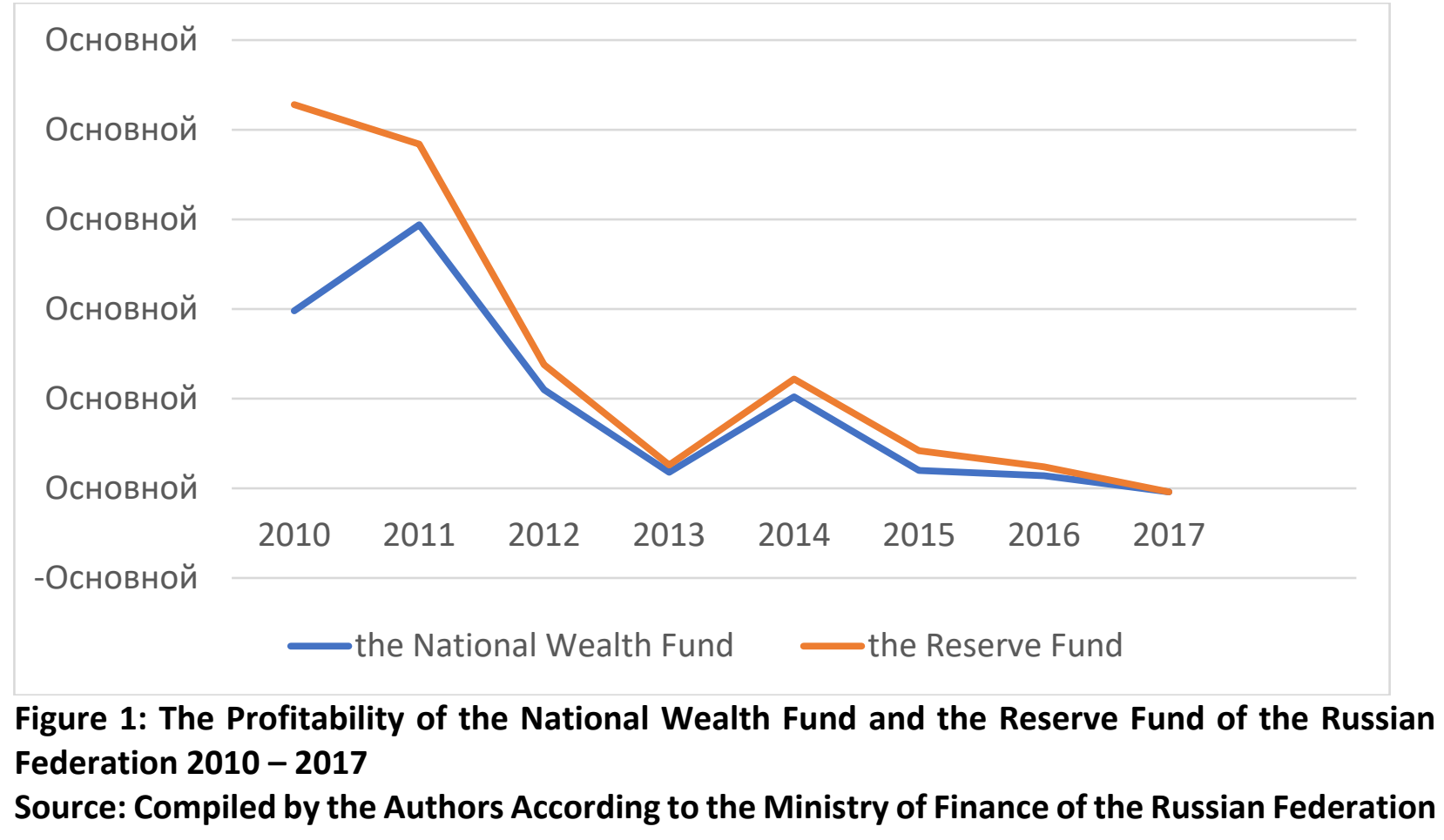

\footnotetext{
${ }^{1}$ High grade in the Moody's Rating Scale Retrieved on 10 April 2019 from,
} 
Due to the fact that currency instruments mainly represent investments, the portfolio is affected by revaluations and the general volatility on the financial market (Osipov et al., 2017, Nikitina et al., 2018). It is possible to state that the form of organisation in terms of the use is also different and is classified in two directions. The funds in the Russian Federation are used mainly to cover the budget deficit. The reserve fund had been actively used from 2015 to 2017 to cover the deficit, and reduced for this period from RUB 4.3 billion down to RUB 994 billion. This is the reason why it was deactivated and merged with the Russian National Wealth Fund on 01 January 2018. Figure 1 shows the funds' profitability.

\section{Discussion}

In the 21st Century, SWFs has been transformed into a new evolutionary form. Nowadays they are not just funds to cover cyclical state budget deficits but have become very powerful financial institutions focused on investments in innovative industries and an efficient form of long-term money to achieve strategic goals in macroeconomics. At the same time, it is possible to positively evaluate the achievement of such a goal as international financial integration based on strengthening the economic relationship between developed and developing markets.

The systematisation and analysis of the foreign practice related to using oil and gas market income made it possible to formulate several conclusions (Plenkina et al., 2018). To reduce the negative impact of foreign economic conditions on the budget, as a rule, the countries exporting hydrocarbons accumulate the earned superprofits either on accounts in central banks or sovereign funds. The fund formation is based on a well-developed strategy of sovereign investments for the state, taking into account the preservation of assets (capital), and obtaining the required volume of profit from investments. The world practice testifies to the predominance of SWFs emerging in resource independent countries and formed from nonenergy sources. The total amount of the formed SWFs in the global economy is USD 7.421 billion, with the countries that use non-energy funds accounting for $39.57 \%$ of this amount.

The investment portfolio of sovereign funds in states varies with respect to riskier assets, the ratio of risk and profitability.

As a rule, the following combination of instruments is used: a basket of currencies of the developed G5 and developing countries, securities of the largest global corporations with a relevant credit rating, real estate and innovative sectors of the economy.

Investing money of the SWF in other countries prevents the excess money supply within the state.

In such a situation, inflation is restrained, and the sustainability of the national currency is maintained. SWFs include infrastructure subfunds. The money accumulated in subfunds is spent on domestic investments in order to finance the most important and problematic areas of the economy. The goals and objectives of forming SWFs correlate with the macroeconomic goals of the country's development. This is due to the fact that the funds' assets have an impact on state finances and the payment balance indicators, as well as on the state of the private sector of the economy. The order of formation and use of funds depends on the degree of impact of various factors: the climatic, the general socioeconomic state of the country, the demographic situation, the efficiency of implementing monetary and fiscal policies.

\section{Conclusion}

The Russian practice of organising and managing SWFs has differences that consist of the active use of funds to cover the budget deficit, as well as a slight investment potential. It is necessary to note that the Russian funds do not act as longterm investments and are not used as instruments to fulfil strategic macroeconomic objectives. The nonfulfillment of the goal in terms of forming pension savings is an extremely important detail because the profitability and goals of the reserve do not correspond to the 
stated ones. This fact confirms that since 2014 the indexation that could be carried out at the expense of the specialised fund (based on the fund's goals) has been frozen. The current profitability of funds is extremely low as compared to the global profitability of investing in risk-free assets and stock market assets. At the same time, there is a trend towards the decrease in the volume of savings accumulated in these financial institutions. Therefore, in 2013 the total amount of funds was $7.9 \%$ of the GDP, and in late 2017, this figure was $5 \%$ of the GDP, which indicated the need to pay more attention to this issue, identify the causes, and develop a longterm strategy and instruments for pursuing an efficient investment policy within the funds and the Russian Federation, as a whole.

\section{References}

Aizenman, J., \& Glick, R. (2009). Sovereign wealth funds: Stylized facts about their determinants and governance. International Finance, 12(3), 351-386. doi: 10.1111/j.14682362.2009.01249.x

Beck, R., \& Fidora, M. (2008). The impact of sovereign wealth funds on global financial markets. Intereconomics, 43(6), 349-358. doi: 10.1007/s10272-008-0268-5

Bernstein, S., Lerner, J., \& Schoar, A. (2013). The investment strategies of sovereign wealth funds. Journal of Economic Perspectives, 27(2), 219238. doi: 10.1257/jep.27.2.219

Bortolotti, B., Fotak, V., \& Megginson, W.L. (2015). The Sovereign Wealth Fund Discount: Evidence from Public Equity Investments. Review of Financial Studies, 28(11), 2993-3035.

Clark, G.L., Dixon, A.D., \& Monk, A.H.B. (2013). Sovereign wealth funds: Legitimacy, governance, and global power. Sovereign Wealth Funds: Legitimacy, Governance, and Global Power, 1, 212.

Cohen, B.J. (2009). Sovereign wealth funds and national security: The Great Tradeoff. International Affairs, 85(4), 713-731. doi: 10.1111/j.1468-2346.2009.00824.x

Dewenter, K.L., Han, X., \& Malatesta, P.H. (2010). Firm values and sovereign wealth fund investments. Journal of Financial Economics, 98(2), 256-278.

Dubovik M.V., Gubarev R.V., Bondarenko N.E., \& Dziuba E.I. (2018). Evaluation of innovative development of Russian regions on the basis of neural network simulation. International Journal of Pure and Applied Mathematics, 119(10), 427 431.

Gilson, R.J., \& Milhaupt, C.J. (2008). Sovereign wealth funds and corporate governance: A minimalist response to the new mercantilism. Stanford Law Review, 60(5), 1345-1369.

Haberly, D. (2011). Strategic sovereign wealth fund investment and the new alliance capitalism: A network mapping investigation. Environment and Planning $A, 43(8)$, 1833-1852. doi: 10.1068/a43324

Helleiner, E. (2009). The geopolitics of sovereign wealth funds: An introduction. Geopolitics, 14(2), 300-304. doi: $10.1080 / 14650040902827740$

Johan, S.A., Knill, A., \& Mauck, N. (2013). Determinants of sovereign wealth fund investment in private equity vs public equity. Journal of International Business Studies, 44(2), 155-172. doi: 10.1057/jibs.2013.1

Johnson, S. (2007). The rise of sovereign wealth funds. Finance and Development, 44(3), 56-57.

Kimmitt, R.M. (2008). Public footprints in private markets: Sovereign wealth funds and the world economy. Foreign Affairs, 87(1), 119-130.

Knill, A., Lee, B.-S., \& Mauck, N. (2012a). Bilateral political relations and sovereign wealth fund investment. Journal of Corporate Finance, 18(1), 108-123. doi: 10.1016/j.jcorpfin.2011.11.002

Knill, A.M., Lee, B.S., \& Mauck, N. (2012b). Sovereign wealth fund investment and the return-to-risk performance of target firms. Journal of Financial Intermediation, 21(2), 315340. doi: 10.1016/j.jfi.2011.10.001

Kotter, J., \& Lel, U. (2011). Friends or foes? Target selection decisions of sovereign wealth funds and their consequences. Journal of Financial Economics, 101(2), 360-381. doi: 10.1016/j.jfineco.2011.03.007 
Monk, A. (2009) Recasting the sovereign wealth fund debate: Trust, legitimacy, and governance. New Political Economy, 14(4), 451-468. doi: $10.1080 / 13563460903287280$

Nikitina, M.G., Pobirchenko, V.V., Shutaieva, E.A., \& Karlova, A.I. (2018). The investment component in a nation's economic security: the case of the Russian Federation. Entrepreneurship and Sustainability Issues, 6(2), 958-967. doi: 10.9770/jesi.2018.6.2(32)

Osipov, V.S., Skryl, T.V., Blinova, E.A., Kosov, M.E., Zeldner, A.G., \& Alekseev, A.N. (2017). Institutional Analysis of Public Administration System. International Journal of Applied Business and Economic Research, 15(15), 193-203. Plenkina, V., Andronova, I., Deberdieva, E., Research Studies Journal, 21(1), 542-554.
Lenkova, O., \& Osinovskaya, I. (2018). Specifics of strategic managerial decisions-making in Russian oil companies. Entrepreneurship and Sustainability Issues, 5(4), 858-874. doi: 10.9770/jesi.2018.5.4(11)

Rose, A.K., \& Spiegel, M.M. (2004). A gravity model of sovereign lending: Trade, default, and credit. IMF Staff Papers, 51 (SPEC. ISS.), 50-63.

Shih, V. (2009). Tools of survival: Sovereign wealth funds in Singapore and China. Geopolitics, 14(2), 328-344. doi: $10.1080 / 14650040902827799$

Sigarev, A.V., Kosov, M.E., Buzdalina, O.B., Alandarov, R.A., \& Rykova, I.N. (2018). The role of chains in the Russian retail sector. European 